\title{
ANALYSIS OF EXPRESSIVE ILLOCUTIONARY ACT IN THE MOVIE ENTITLED THE CONJURING 2
}

\author{
Ni Kadek Noviarianti Karisma Dewi', Ni Made Verayanti Utami \\ Mahasaraswati Denpasar University, Indonesia ${ }^{12}$ \\ deknovi98@gmail.com, verayanti.utami@unmas.ac.id
}

\begin{tabular}{|c|c|}
\hline & ABSTRACT \\
\hline & Language is one the foremost necessary ability \\
\hline Journal History & $\begin{array}{l}\text { folks use to interact with others. The fascinating } \\
\text { phenomena in illocutionary act is the act are often }\end{array}$ \\
\hline Submitted 17th December 2021 & use not just concerning what the speaker \\
\hline Revised $14^{\text {th }}$ January 2022 & vocalization. The study aims to investigate the \\
\hline Accepted 15th January 2022 & kinds of expressive illocutionary act found in the \\
\hline Published 24 th January 2022 & movie The conjuring 2 and also the context \\
\hline & $\begin{array}{l}\text { situation supports in the movie the conjuring } 2 \text {. } \\
\text { This study the writer used some methods there are }\end{array}$ \\
\hline & $\begin{array}{l}\text { Aescriptive qualitative and quantitative methoa. } \\
\text { And also used some theories, first from Searle }\end{array}$ \\
\hline Keywords: & $\begin{array}{l}\text { (1979) theory of types illocutionary act, Halliday } \\
\text { and Hassan (1985) theory context situation. Based }\end{array}$ \\
\hline $\begin{array}{r}\text { expressive, illocutionary, } \\
\text { movie }\end{array}$ & $\begin{array}{l}\text { on the data, there are } 32 \text { utterances found in the } \\
\text { movie with } 6 \text { types there are }(22 \%) \text { of thanking, } \\
(16 \%) \text { of apologizing, }(22 \%) \text { of attitude, }(28 \%) \text { of } \\
\text { greeting, }(9 \%) \text { of wishing, (3\%) of congratulating } \\
\text { and field, tenor, and mode as the context of } \\
\text { situation found in the movie the conjuring } 2 \text {. }\end{array}$ \\
\hline
\end{tabular}




\section{INTRODUCTION}

In daily life, as a people communication is very important to interact with other. In communication with other people must use an appropriate language to avoid the misunderstanding. People as social being need interact because communication is very important thing at anywhere and anytime (Yuniati, 2018). With communication people can deliver their information, mind and their feeling. When the people do some conversation with others, some expression produced by them, not only just utterance but they tried to show some action through the expression. However, as the speaker who tried to convey the information, misunderstanding can be found. To avoid this situation, speech act as one part of pragmatics study exist to solve that problem. In pragmatics study, speech act is one the aspects in pragmatic. The concepts about speech act develop by Austin (1962). Austin (1962:2) defined there are three types of speech act such as locutionary act, illocutionary act and perlocutionary act.

Illocutionary as the one of part in speech act is commonly to analyzed in real life and important to analyze to understand the intended meaning of utterance. Searle (1979) proposed that there are five different types in Illocutionary act, there are representative or assertive, commissive, directive, expressive and declarative. As the one of type in illocutionary act, expressive is the type that use to express the speaker's emotion or attitude to the hearer. Searle (1979:15) states expressive illocutionary act is the psychological state specified in the sincerity condition about a situation specified in the proportional content. The expressive include thanking, apologizing, attitude, greeting, wishing, congratulating. Thanking is an utterance used to expressing the gratitude to someone. Apologizing is types to express of some regrets which related with ask forgiveness, beg pardon and so on. Attitude is about the expresses felling disagree about some the speaker said. Greeting is an utterance that aims to express of welcoming someone and the action to greeting someone. Wishing are some expression of the speakers wants or desire something it becomes reality. Congratulating is used to express the feeling of pleasure to the hearer's luck. According to Halliday and Hasan (1989:12) proposed there are three parts context of situation such as: field, tenor, and mode. Field refers about the activity and what is happening, where, when and why it is happening. Tenor refers about the participants and who is involved. Their status, and roles or what types the role relationship between the participants. Mode refers about what part of language is playing, what it is that the participants are expecting the language to do for them in the situation.

The writer would like to show five a similar study from the other previous research that were analyze about Expressive illocutionary act. The first study was done by Muliawati, Sedeng and puspani (2020) in her study entitled The Expressive Illocutionary Acts Found in Webtoon True 
Beauty and Their Translation into Indonesia. The aims of this study were to find out the expressive illocutionary act found in the comic and analyze the technique of translation comic True Beauty. The theory used in this study proposed by Leech (1993) about the theory of speech act and proposed by Hymes (2009) the theory of translation technique written by Molinda and Albir and ethnography of speaking. The second study by Handayani (2015) entitled The Use of Expressive Speech act in Hannah Montana Session 1. The aims of this study explain about the kinds and form of expressive speech act in Hannah Montana Session 1. The writer found ten kinds of expressive speech act. The theory that her used proposed by Searle (1976) and by Yule (199:53) the types of expressive illocutionary act.

Third study by Amalia and Aziz (2017) entitled Expressive Illocutionary Acts A Tool in An English Classroom: A Method To Encourage Students To Speak More. The aims of this study were described and analyzed types of expressive illocutionary act uttered by the teachers in the classroom in relation with a social distance dimension. The writer used the theory by Searle in Cutting (2002) and relates to expressive illocutionary acts with social distance dimension by Homes (2002). A supporting theory by Mc. Mannis et al (1987) about context theory and by Yule (199) about a direct and indirect Speech Theory. fourth, the study by Ranteg (2019), entitled An Analysis of Expressive Illocutionary act in the movie Beautiful Creatures. The aims of this study to find out the types expressive illocutionary act in the movie Beautiful Creatures and the context of the situation. The writer also used some theory to do this study, the theory proposed by Searle (1979) and supporting by Austin (1962), the second theory proposed by Halliday about the illocutionary act of context situation. Fifth the study by Siregar (2018) entitled A Study of Expressive Act Used by The Characters in Orphan Movie Script. The study aims to find out the kinds of expressive speech act and the most dominant of expressive speech act in movie. The writer applied some theory for this study proposed by Searle (1976) to analyze expressive speech act in the movie.

Expressive is an illocutionary act that used to express the feeling of the speaker. In daily life expressive commonly used by the people some types such greeting and thank you usually used in the conversation. Expressive can be found when the people meet someone they know, at least they must act right expression such as expressed their greeting or welcoming and can be found in the daily conversation. This study aims to explain the kinds of expressive illocutionary act and the context of situation in the movie The Conjuring 2.

\section{METHODS}

This study used a movie as the data. The data of this study was taken from The Conjuring 2 movie. The data were collected by observation 
methods by watching the movie and note taking. The data were classified into types of expressive illocutionary act such as: Thanking, attitude, greeting, apologizing, wishing, congratulating. Then, the data was analyzed with descriptive qualitative method by using some theories. First theory from Searle (1979) to classifying the types illocutionary act, second used theory by Halliday and Hassan (1985) to analyze the context situation of expressive illocutionary act. The formal and informal method was used in presenting the data.

\section{RESULT AND DISCUSSION}

\section{RESULTS}

This part explained the findings of the study, which is containing in the table and shows the types expressive illocutionary act occurred in the movie The Conjuring 2 and here the types of expressive illocutionary act found in the movie explained in the table below.

Table 1. Types of Expressive Illocutionary Act Found

\begin{tabular}{c|ccc} 
No & $\begin{array}{c}\text { Types of } \\
\text { Expressive } \\
\text { Illocutionary } \\
\text { Act }\end{array}$ & $\begin{array}{c}\text { Number of } \\
\text { occurances }\end{array}$ & Percentage \\
\hline $\mathbf{1}$ & Thanking & 7 & $22 \%$ \\
\hline 2 & Apologizing & 5 & $16 \%$ \\
\hline 3 & Attitude & 7 & $22 \%$ \\
4 & Greeting & 9 & $28 \%$ \\
5 & Wishing & 3 & $9 \%$ \\
6 & Congratulating & 1 & $3 \%$ \\
\hline Total & & 32 & $100 \%$ \\
\hline
\end{tabular}

Based on the analysis of expressive illocutionary act, this study shows that there were six types of expressive illocutionary act used by the characters in the movie The Conjuring 2. The six types there are thanking, attitude, greeting, apologizing, wishing, congratulating. The total of the data it can be shown in the table below. The highest data is greeting reached 9 data $(28 \%)$. It is indicating that the speaker welcoming someone and greet the speaker to the hearer. Expressive of greeting is the highest data because it is often used in the movie. Expressive apologizing reached 5 data $(16 \%)$, attitude reached 7 data $(22 \%)$, thanking 7 data $(22 \%)$, wishing 3 data $(9 \%)$, Congratulating 1 data $(3 \%)$.

\section{DISCUSSION}

Expressive is one of kind illocutionary act used to express the feeling or emotional states of the speaker. Based on Searle (1979) states 
expressive illocutionary act is used to express the psychological state in sincerity condition. This act includes like thanking, greeting, apologizing, attitude, wishing, congratulating. The discussion part will explain each type of expressive illocutionary act by analyzing and describe the utterance of each types support with the context of situation. There are 6 selected examples are presented in the discussion.

\section{Thanking}

Thanking is one of types expressive illocutionary act that used to express the gratitude from the speakers to the hearer. In The Conjuring 2 movie there are 7 utterance that classified as Thanking. Here the example from the expressive of thanking.

\section{Data 1:}

Mr. Maurice : Mr. and Mrs. Warren, I' m Maurice Grosses. Thank you so much for coming. I believe you're gone be staying at the Hodgson's house, it's that right?

Ed Warren : Always better to be in the mix.

(The Conjuring 2, 01.02.15)

In the conversation between Mr. Maurice and Ed Warren is categorize of expressive thanking because in the utterance "Thank you so much" the speaker tried to express her gratitude to the hearer by utterance "thank you so much for coming." then the utterance "thank you" can categorize as a type of expressive thanking, because in this utterance containing the expressive of gratitude. And based on the theory the expressive of thanking is the expression of the speaker used to express she / he gratitude.

\section{Context of Situation}

Field : field is talks about what happened and where the conversation happened. in the conversation happened in Marylebone Station, when Mr. Maurice picks up Mr. And Mrs. Warren who just come from America. In this situation Mr. Maurice will take Ed and Lorrain to Mrs. Hodgson's house with aims to make sure of the strange events that happened in that house. In this scene, Janet as a Mrs. Hodgson daughters has been possessed by the spirit named Bill.

Tenor : Tenor used to analyze the participants. In the conversation before the participants were Mr. Maurice, Ed Warren and Lorraine Warren. Mr Maurice is an Engineering consultant. He was involved in this case because he felt sorry to Hodgson's family and want to help them. 
Then, Ed and Lorraine Warren are the paranormal investigator who has handled many similar cases as the haunted house.

Mode : the mode of the conversation is Maurice as the speaker. This expressive illocutionary act was uttered by spoken mode because he speaks with orally way. The conversation can consider as an informal way because the situation is not in formal it is happened in the station and Here Mr. Maurice as the older person started a casual conversation by just calling Mr. and Mrs. Warren without greeting first. Here Mr. Maurice wants to seem familiar with them.

\section{Data 2:}

Mr. Hodgson : : Thanks for coming back

Mrs. Lorraine $\quad$ : It's alright

(The Conjuring 2, 02.04.06)

Based on the theory of expressive illocutionary act the utterance "Thanks" by Mrs. Hodgson can be classified into the expressive of thanking. In this situation Mrs. Hodgson as the speaker tried to convey her feeling gratefully to Mrs. Lorraine as the hearer who decide come back to help her family.

\section{Context of situation}

Field : Field in the conversation were happened in near Mrs. Hodgson's house street. It is happened when Ed and Lorraine Warren decide to come back at Mrs. Hodgson's house after before they choose to leave the Hodgson's family because they think all the case is fake. Then, after they back they saw Janet in a dangerous situation but finally Ed and Lorraine Warren success to save Janet who is possessed by a spirit. The next day, after the situation is good Ed and Lorraine Warren sit down in back ambulance car to get rest Mrs. Hodgson come to Lorraine and hug her while saying Thanks.

Tenor: Tenor or the participants in the conversation above were Mrs. Hodgson, Lorraine, Ed Warren, Janet. Mrs. Hodgson's is Janet's mother. She is a single mother who lives with her four children. Ed and Lorraine Warren are a paranormal investigator who helped the Hodgson's family to saves Janet from the devil spirit.

Mode: The mode in this utterance is Mrs. Hodgson's as the speaker she was express her grateful feeling to ed and Lorraine Warren as the hearer who has help her children. The expression was uttered by spoken mode because she conveys her expression with orally way. 


\section{Attitude}

Attitude is part of expressive illocutionary act to express the feeling disagree or dislike. Based on the analysis before, the writer found 7 utterances of attitude. There are two examples the utterance of Attitude expressive illocutionary act.

\section{Data 3:}

Ed Warren : Why don't you just leave these people alone?

Bill : Because this is my house!

Ed Warren : It's not your house!

(The Conjuring 2, 01.13.19)

The utterance "it's not your house" produced by Ed Warren can be categorize as an attitude because Ed Warren as the speaker disagree about the statement by the hearer. In the situation, Ed Warren talking with Bill who already possessed in Janet bodies. Bill claims the house it his mine then, Ed Warren disagrees about that because in the fact that house is Mrs. Hodgson's house beside Bill is already gone, well Mrs. Hodgson is the legal owner of the house. That is why the utterance "it's not your house" can categorize as the attitude expressive illocutionary act because, Ed warren tried to convey her feeling by that utterance.

\section{Context of Situation}

Field : The field in the conversation happened in Mrs. Hodgson's house at Enfield London in the afternoon when Ed Warren and Lorraine arrive for the first time in Hodgson's house and tried to talk with Janet and doing some activity to calling the spirit through Janet's body. When the spirit success in Janet's bodies and talking together with ed warren claims if the house is his mine, then Ed Warren said it's not him house and said to leave the Hodgson's family.

Tenor : the participants in the conversation were Ed Warren as the speaker, Bill and Janet. Ed Warren as the paranormal investigator who tried to help Hodgson's family start his first activity through talking with Bill. Bill is a spirit who always possessed in Janet's Bodies. Before, when he was alive, he lives in that house. After he died, he still felt that house was still his and wanted to meet his family even though his family had long gone and sold the house.

Mode : the mode in the conversation is Ed Warren as the speakers express his feeling towards the hearer Bill. With utterance "it's is not your house" Ed disagrees about what the hearer said. The utterance produces with the spoken mode and can considered informal way because the situation is not formal it is happened in the living room and in the Mrs. Hodgson's House. 


\section{Data 4:}

Mrs. Hodgson : : My girl didn't make this up, I've seen things.

Anita Gregory : : She was caught red handed faking an even.

(The Conjuring 2, 01.40.13)

Based on the theory of expressive illocutionary act the utterance produce by Mr. Hodgson's can be classified as the attitude. The utterance "my girl didn't make this up" is an utterance of the speaker to convey her emotional to disproval from something the hearer said. In the situation of the conversation Anita said if Janet faked all this events and Mrs. Hodgson's believe her daughter cannot do that.

\section{Context of the situation}

Field : The conversation above took place in the Mrs. Hodgson house in the night. When all people get panic because they lost Janet who possessed by spirit and then when Anita Gregory get the video and saw if Janet consciously destroying all the items in the kitchen. It is the reason why Ed and Lorrain stop they investigate because the proof shows that Janet Faked all this events. But Mrs. Hodgson still didn't believe if Janet faked that event. Asa mother he felt sad and disappointed because they said that her daughter was lying.

Tenor: the tenor the participants in the conversation above were Mrs. Hodgson. As the speaker who disagree about the something the hearer said. There is Anita Gregory is a parapsychologist and lecturer at the polytechnic of North London. From the first time she didn't believe about this case and just think this just usually hallucinations from the children.

Mode : the mode of the utterance that used by Mrs. Hodgson's used spoken mode in informal way. Because the speakers used orally way and the situation it is happened in the Mrs. Hodgson house and this can consider not formal.

\section{Apologizing}

Apologizing is type of expressive illocutionary act that use to express her/his regret. After the analysis this study, the writer found five utterances apologizing from the data. Here one of the examples from the expressive of apologizing:

Data 5:

Ed Warren : : where'd you get it from?

Mrs. Hodgson : My ex-husband bought all the furniture with the house when we move in. 


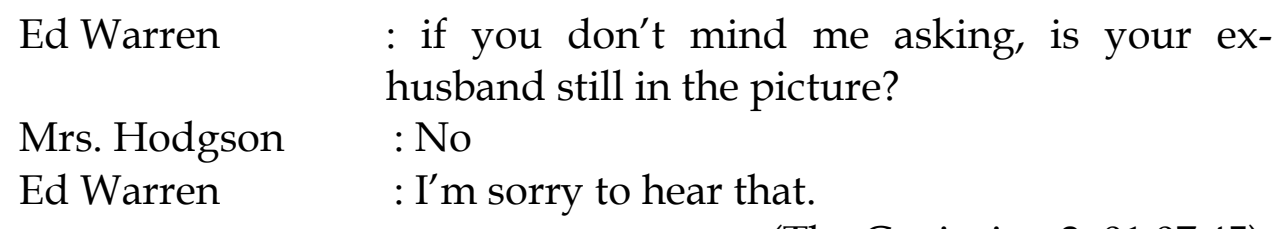

(The Conjuring 2, 01.07.45)

Based on the theory the utterance "I'm sorry to hear that" can classified into expressive illocutionary act of apologizing. In the context the speaker tried to express her feeling to the hearer. The words "I'm sorry" mean the speakers feel regret for what happened to the hearer.

\section{Context of Situation}

Field : the field in the conversation happened in Mrs. Hodgson's house in their living room. Where Bill as the spirit usually sit down in the sofa. The situation when Mrs. Hodgson tried to explain about what happened in their house and when this is the first time Ed Warren arrive in her house.

Tenor : the tenor or the participants in the conversation were Mrs. Hodgson and Ed Warren. Mrs Hodgson as the owner the house tried to explain what happened in her house and her daughter Janet to Ed Warren who arrive for the first time in Mrs. Hodgson's house as a paranormal investigator.

Mode : the mode in the conversation were ed Warren As the speaker express his feeling with spoken mode to Mrs. Hodgson as the hearer. This conversation can consider as an informal way because the situation happened in the house and the utterance used by casual way.

\section{Data 6:}

Lorraine : Is that why you're doing this? Because you want to be a part of something historic? This isn't a laboratory this is someone house. And I thing helping that family is the only thing that matters.

Mr. Maurice : No. I'm Sorry, I didn't mean that.

(The Conjuring 2, 01.29.57)

Based on the theory expressive illocutionary act by Searle (1979), Apologizing is the utterance speaker produce to express their regret. The utterance "I'm sorry" can classified as the types of apologizing because this utterance containing some regret by the speakers. In this situation Mr. Maurice say sorry to Lorraine because the reason he come join to this investigation not just she wants to become a historic, but he honestly wants to help Mr. Hodgson. family 


\section{Context of Situation}

Field: The field in the conversation happened in front Mrs. Hodgson house at night when Mr. Maurice and Lorraine talk about how the calm the situation in the house. And here Lorraine talks if Mr. Maurice just want a become historic that's the reason why he joins in this investigation and Mr. Maurice says sorry because make Lorraine misunderstanding about him.

Toner: The participants in this conversation were Lorrain as the speaker. she is wife of Ed Warren and as the paranormal investigators who want to help Mr. Hodgson's family. And Mr. Maurice as the hearer is an Engineering consultant who volunteered to help the Hodgson's family.

Mode: The mode in the conversation were Mr. Maurice as the speaker used spoken mode to express his feeling towards the hearer in informal way. Because they just used a daily conversation, and the place is not formal is just happened in the front of Mrs. Hodgson's house.

\section{CONCLUSION}

This study analyzed types of expressive illocutionary act in the movie The Conjuring 2 and how about the context of situation support in the expressive illocutionary act. Based on the result and discussion above, it can be concluded that here were 32 data of expressive illocutionary act found in the movie The Conjuring 2. The result shows that there are 6 types of expressive illocutionary act that found in the movie The Conjuring 2. There are Thanking, Apologizing, Attitude, greeting, wishing, congratulating. For the thanking found 7 utterance $(22 \%)$, apologizing found 5 utterance (16\%), Attitude found 7 utterance (22\%), Greeting found 9 utterance $(28 \%)$, Wishing found 3 utterance (9\%), Congratulating found 1 utterance $(3 \%)$. Thanking is an utterance that used to express the gratitude to the addresses. Apologizing is an expression from the speaker to deliver their regret. Attitude is the expression when the speakers disagree or dislike about something the hearer said. Greeting is an utterance that used to welcoming or greet someone we know, or we meet. Wishing is an utterance that used the speaker desire something and expect it become reality. Expressive congratulating that used to shows the speakers sympathy towards the hearer. Based on the data the highest from six types Expressive illocutionary act is expressive greeting found 9 utterance $(28 \%)$. Greeting is the most utterance used by the character in the movie. The characters used utterance greeting to welcoming or to greet someone. 


\section{REFERENCES}

Austin, J.L. 1962. How to do Things with Words. London: Oxford University press.

Amelia Mita, Aziz Angela. 2017. Expressive Illocutionary Act as A Tool in an English Classroom a Method to Encourage Student to Speak More. Aceh: Padjajaran University. Article, (1), 9-17.

Halliday, Michael, and Ruqaiya Hassan. 1989. Language, Context,and Text: Aspects of Language in a Social-Semiotic Perspective. Oxford: Oxford University Press.

Handayani, Nur Vita. 2015. The Use of Expressive Speech Acts in Hannah Montana Session I. REGISTER: Register Journal,8(1),99-112.

Muliawati, N.W., Sedeng, I.N., \& Puspani, I. A. M. 2020. The Expressive Illocutionary Acts Found in Webtoon True Beauty and Their Translation into Indonesia. RETORIKA: Jurnal Ilmu Bahasa,6(2),148-155.

doi: http://doi.org/1022225/jr.6.2.1802.148-155

Ranteg, Dinda Belinda. 2019. An Analysis of Expressive Illocutionary Act in the Movie Beautiful Creatures. Denpasar: Mahasaraswati Denpasar University.

Searle, J.R. 1979. Expression and Meaning. Cambridge: Cambridge University Press.

Siregar, Dina Mariani. 2018. A Study of Expressive Speech Act Used by the Characters in Orphan Movie Script. Medan: University of Sumatera Utara Medan.

Syahputra, M. Haryadi. 2015. An Analysis of Expressive Illocutionary Acts in the Oprah Winfrei Show. Medan: University of Sumatera Medan

Yuniati, Asmi. 2018. Directive Speech Acts in The Movie The Message By Moustapha Akkad. Semarang: Education and Teacher Training Faculty of Walisongo State Islamic University 